\title{
Submission Unit Type Code
}

National Cancer Institute

\section{Source}

National Cancer Institute. Submission Unit Type Code. NCI Thesaurus. Code C94167.

A coded value specifying the kind of submission unit. 